\title{
BCR-ABL TKI-Resistant Mutation
}

National Cancer Institute

\section{Source}

National Cancer Institute. BCR-ABL TKI-Resistant Mutation. NCI Thesaurus. Code

C110963.

A molecular genetic abnormality in the kinase domain of the BCR-ABL fusion gene that results in resistance to tyrosine kinase inhibitors. 